\title{
ENGLISH BORROWINGS \\ IN ROMANIAN COMPUTER TERMINOLOGY
}

\section{Introduction}

The dynamic pace of computer technology is rapidly changing the world we live in. It goes without saying that English has been the dominant language in the world even if in recent years this dominance has begun to subside. Nevertheless, it has acquired the status of the language for international communication since international academic conferences and congresses, trading relationships, politics, diplomacy, tourism, aviation and most world organizations use English as their language for communication as Crystal (1997) pointed out. It is also the language of science and technology since scientists all over the world publish their papers, articles, books and Doctoral dissertations in English to facilitate the world-wide exchange of information. Furthermore the main scientific journals are published in English.

It has also been described as the language of computers. This was due to several reasons. One of them is related to the fact that the first computing device was attributed to Charles Babbage, an English mathematician and pioneer of computer science, who designed the first automatic computing engines in 1822. Furthermore the electronic revolution occurred in the USA in the 1970s and overall, as Crystal (1997: 121) put it, "the development of the twentieth-century computers has been almost entirely an American affair". The emergence of personal computers in the 1980s (known as IBM 5150 PC launched by IBM in 1981 in the United States of America) witnessed an unprecedented boom. The internet was also invented in the USA and was officially launched in 1983 as well as the browser that paved the way to the World Wide Web. In addition, David Crystal (1997) estimated that $80 \%$ of the information displayed on the internet is in English. Therefore the vocabulary of computing, the internet, the search engines are all in English, whose powerful influence has also been exerted over the programming languages (most of them were designed and developed in an English-speaking country and used in countries where English is not the first language). Even if it is not the only language used online today, English is still the dominant language (Greiffenstern 2010: 6). 
Consequently, English-based words emerge frequently in this terminology to denote realities that do not have equivalents in other languages. Subsequently these new words spread globally and are adopted unchanged to fulfil communicative needs.

However linguists have repeatedly expressed their concerns that English might deteriorate the host languages. David Crystal (2001) envisaged the powerful impact of this linguistic phenomenon and emphasized that "technospeak will rule, standards be lost, and creativity diminished as globalization imposes sameness". On the one hand the internet can be regarded as an enormous resourceful medium for languages, facilitating the process of word expansion worldwide. On the other hand it could endanger the future of languages, posing a real threat to linguistic and cultural diversity.

Romanian is one of the languages that have been massively adopting words from English. Numerous words that belong to this terminology fell initially into the category of neologisms but due to their extensive use, they migrated to the general language. Consequently a very large stock of English borrowings has already been listed in the Romanian dictionaries. These words are so common nowadays that they are no longer perceived as foreign.

\section{Literature Review}

The phenomenon of English borrowing has been widely discussed in the Romanian academic community in recent years. From complex, largescale projects (Filipović 1985, Görlach 2001, Stoichițoiu Ichim 2001 and others) and PhD dissertations (such as Ciobanu 2004, Athu 2011) to conference papers, there has been a constant concern of shedding light on this aspect, providing normative, descriptive and practical approaches. Some of them focussed on the inventory of English words listed in Romanian dictionaries and which are now part of the Romanian lexis. Others attempted at clarifying why the Romanian people displayed such a strong tendency of using English borrowings instead of Romanian words, especially after the fall of the communist regime.

Defined by Thomason and Kaufman (1988: 37) as

"the integration of foreign features into a group's native language by speakers of that language: the native language is maintained but is changed by the addition of the incorporated features",

English borrowings can be found in all language compartments but their number in fields such as technology and science, aviation, computer science (Görlach, 2002: 102) is higher. In recent years the same trend has 
been witnessed in medicine, politics, computer-mediated communication or tourism.

Linguists prefer different terms to refer to this category of words such as loanwords, Anglicisms, borrowings, neologisms, barbarisms. Braun et al (2003) (apud Van Sterkenburg, 2009) emphasize the presence of internationalisms in numerous world's languages, referring to words of English or American origin, which, on the one hand can enrich the vocabulary of a language, facilitating intercultural communication but on the other they can have a negative impact upon a language. Popescu (2015: 99) uses the term foreignisms to denote borrowings from all foreign languages, explained as „words which were calqued from another language, bringing along with them spelling and sometimes their phonetic features".

Most Romanian linguists accept the broad outlines of the classification established by Pușcariu in 1940, who distinguished between necessary borrowings and needless borrowings. Basically he distinguished between denotative and connotative borrowings. It is worth noting here that the majority of English terms borrowed in this terminology fall into the category of necessary or denotative borrowings, i.e. they designate new notions, objects or concepts that emerged relatively recently in English and for which there is no Romanian equivalent such as server.

However, there are several examples of lexical doublets, i.e. words adopted from English that just double the existing Romanian terms. The main reasons for using the English word instead of the Romanian one is that it may display certain advantages such as conciseness in communication (specialist jargon) or speeding up the dissemination of information such as

high-tech / tehnologie de vârf, network / rețea, user / utilizator, screen / ecran, printer / imprimantă, kernel / nucleu, debugging / depanare, provider / furnizor, password / parolă, internet provider / furnizor de internet, search engine / motor de căutare.

Linguists concur that the necessary borrowings contribute to the modernization of the host language, updating it with the new terminology.

\section{Findings}

One of the first Romanian dictionaries published after the fall of the communist regime listed several words related to this terminology, most of them adopted unassimilated such as:

$C D<$ compact disk, $C D$-Rom < compact disk read only memory, chip, a computeriza $<$ to computerize, computerizat < computerized, computer, digital, display, E-mail, 
gadget, hacking, hard-disk, hi-fi, home-computer, internet, laser, monitor, monitoring, $P C<$ Personal Computer, sensor, software, toner and others.

The more dynamic the pace of computer technology, the more new words or new meanings added to the existing words that transgressed with their original form and pronunciation into Romanian in the years to come:

hardware, input, scanner, up-to-date, CD-writer, desktop, high technology, laptop, layout, output, print, provider, server, service, slash (Ciobanu, 2004, Radu, 2009).

Today, when it comes to word formation in computer science, the newly emerged concepts are adopted almost instantly. An example in case is the privacy law, enforced on May 25th 2018, GDPR < General Data Protection Regulation that was adopted with Romanian spelling: Ce este GDPR, pachetul de legi care ar trebui să ne apere datele personale (iLikeIT, Știrile PROTV, May 5th 2018)

Drawing on previous attempts to classify the English borrowings adopted in the Romanian terminology of computer science (Opriț-Maftei, 2018) the present paper suggests a more comprehensive classification:

- English words that have already been assimilated into the Romanian language, passing into everyday use like procesor, convertor, e-mail, pixel, computer, internet, online, digital, modem, cursor: Tehnologia laser este rezultatul colaborării intre Logitech și Agilent Technologies, specialist in tehnologia mouse tracking, care permite utilizatorului să determine cât de repede se mişcă mouse-ul (cursorul de pe ecran se mișcă proporțional). (Zf, 12 Decembrie 2018);

- funny and easy-to-remember metaphors which have been adopted incorporated into the common language and used by the public at large, such as: bug, mouse, click, drag, burn, recycle bin, tool, Bluetooth, cookie, cut and paste: Apple a prezentat a treia versiune a sistemului de operare pentru iPhone, care suportă acum mult solicitată funcție cut/paste, oferind dezvoltatorilor software noi oportunități pentru a-și vinde aplicațiile (Zf, 14 December 2018);

- words fully or partially adapted to the Romanian morphology verbs: a accesa $<$ to access, a downloada $<$ to download, a formata $<$ to format, a forwarda $<$ to forward, a printa $<$ to print, a (re)seta $<$ to (re)set, a updata < to update, a uploada < to upload, a downgrada < to downgrade: Cifra include, de asemenea, companiile care achiziționează sistemul, dar aleg să facă un downgrade in favoarea XP. (Zf, 26 October 2018), a scana < to scan: Două decenii de Google: de la un simplu site care scana paginile de internet la o companie de 830 miliarde de dolari (Zf, 7 September 2018); nouns: ruter < router, arhivare < archive, interfața < interface, upgradare < 
upgrade, atașament < attachment, updatare < update: dotarea cu un soft antivirus, instalarea unui firewall, updatarea periodică a computerului (Zf, 26 January 2018);

- English adjectives are mainly adopted unassimilated and remain invariable in Romanian such as cutting-edge, user-friendly, online, offline, hi-tech, antivirus, green;

- specialized words and derivatives denoting concepts that transgressed into the Romanian language with their original form and meaning: cluster, router, pad, download, website, spam, display, network, driver, input, output, file, folder, monitor, desktop, hardware, software, delete, Google, copy, paste, file, folder, downtime, smartphone, flood/flooding, cloud, laptop, gadget: Huawei: Veniturile din gadgeturi aproape că s-au dublat în acest an în România. (Zf, 31 October 2018);

- highly specialized English computer-related words, retained with their original spelling and used by a restricted category of people (computer specialists): host, template, link, pixel, console, debugging, firewall, Linux, Mozilla, wireless, android, thread, template, cloud, crawler, daemon, default, tethering, snapshot, token, phishing: Numărul de atacuri de phishing a crescut cu 27,5\%, depăşind 137 de milioane în T3. (Zf, 9 November 2018)

- orthographically unassimilated compounds adopted with their original meaning and pronunciation: database, desktop, keyboard, keypad, hyperlink, mainframe, spreadsheet, webserver, hard drive, home page, input device, output device, internet cookies, website address, word processor, hard disk, screen saver, service-pack, data brokers, web developer, web designer, graphic design, web page, web crawler, stylus pen, remote debugger, mouse tracking, machine learning: Dezvoltarea infrastructurii 5G va permite crearea şi implementarea unor noi produse şi servicii, atât pentru operatorii telecom, cât şi pentru jucătorii din diferite sectoare ale economiei, acestea bazându-se pe tehnologia inteligenției artificiale şi machine learning. (Zf, 16 October 2018)

- acronyms, initialisms and abbreviations borrowed from English which preserved their original pronunciation: IP (Internet Protocol), CPU (central processing unit), PC (Personal Computer), IBM (International Business Machines); IT (Information Technology), ITEC: Pentru că sectorul ITEC din România să continue să crească, statul trebuie să creeze un cadrul legal şi fiscal favorabil dezvoltării industriei de tehnologie. (Zf, 16 October 2018)

- acronyms, initialisms and abbreviations adopted from English but used with Romanian pronunciation: $p d f$ (portable document format), HD 
(high definition), www (World Wide Web), CAD (Computer Aided Design), HTML (Hypertext Markup Language), HDD (Hard Disc Drive), RAM (Random Access Memory), USB (Universal Serial Bus), SSH (Secure Shell);

- clippings: doc < document, giga < gigabyte, mega < megabyte, sysadmin < system administrator, net < internet, wi-fi < wireless fidelity;

- eponyms used with Romanian pronunciation: HP - after the names of Bill Hewlett and David Packard, the founders of the company;

- hybrid constructions that associate an English term with a Romanian one: piață de soft, department de software, servicii de streaming, portal web, fișiere dump, ferestre de browser, format high-definition, unealtă de hacking, serviciu tethering, furnizor de hosting, versiune free-trial, portal de business, serviciu Web, adresă IP, memorie USB, interfaţă USB, Departament RED, Departament IT, imagine HD/full HD, domeniu SEO, servicii SEO, domeniul IT, tehnologie blockchain: China adoptă deja tehnologia blockchain şi cea de inteligență artificială în lupta cu evaziunea fiscală. (Zf, 25 May 2018);

- collocations adopted unassimilated or translated literally: adjective + noun: desktop computer, educational software $\rightarrow$ software educațional, antivirus software $\rightarrow$ program antivirus, home computer, cache memory $\rightarrow$ memorie cache, online (cloud) backup: Telekom România a lansat o soluție de back-up în cloud pentru companiile care lucrează cu volume mari de date (Zf, 13 July 2018); noun + noun: internet provider, computer hardware/software, computer expert, software engineer, user interface $\rightarrow$ interfață utilizator, internet portal, memory stick $\rightarrow$ stick de memorie, internet connection $\rightarrow$ conexiune la internet; verb + noun: to access/use the internet $\rightarrow$ a folosi internet: Aproape patru din zece IMM-uri folosesc internetul pentru a face plăți online. (Zf, 2 January 2018), to restart a computer, to configure a server $\rightarrow$ a configura un server, to reboot a computer, to connect to the internet $\rightarrow$ a se conecta la internet, download a file/software/information $\rightarrow$ a downloada un fissier/program/informații, to zip/unzip the files $\rightarrow$ a comprima/decomprima fissiere, to rename a file, to make a backup $\rightarrow$ a face un backup, to reset a router $\rightarrow$ a restarta un route: FBI-ul a avertizat vineri că „oricine deține un router de internet acasă sau la muncă" trebuie să îl restarteze, pentru a reduce riscul de a fi expus atacurilor cibernetice de tip malware (Zf, 28 May 2018);

- phrasal verbs and phrasal nouns adopted unassimilated: backup, start up, shut down, sign in, sign up, scroll down, add in, add on, click on, put in, pop up, hack into, plug in: se bazează pe plug-in-uri ce trebuie descărcate pe calculator (Zf, 15 November 2018) and adaptations to the Romanian 
morphological system: a face backup < to backup/to make a backup, a face zoom-in/out < to zoom in/out, a clica pe la da click pe < to click on: De asemenea, portalul are cea mai mică rată de respingere de pe piață, sub 30\%, ceea ce înseamnă că cititorii nu dau doar click pe ştiri, ci le şi citesc până la final. (capital.ro, 14 December 2018).

Most English borrowings adopted in this field fill a lexical gap and their use is justified since finding appropriate equivalents is rather challenging. However, it is worth noting that computer science is a highly interdisciplinary terminology, including words specific to other related fields.

Even if timid attempts have been made to render the meaning of certain computer-related English words, these resulted in either long explanatory paraphrases or sometimes the Romanian versions sound unnatural in the target language. Consequently not only the young people but also the average educated ones prefer to use the English term with its original phonetic form instead of the Romanian equivalent (several examples in point are: back-up instead of copie de rezervă or (memory) stick instead of baghetă de memorie, link instead of legătură, switch instead of comutator de rețea). These widely accepted terms are mainly preferred instead of their translations due to their precise, unambiguous and internationally-recognized meaning.

\section{Conclusions}

Slowly but steadily, digital technologies have penetrated into almost all spheres of our lives, influencing world languages with new terms.

As demonstrated, the Romanian language of computer science holds an impressive number of English borrowings denoting computer-related realities, entities and processes, which have been incorporated unadapted mainly due to their informative function. However even when there are Romanian equivalents, the tendency is to use the English words for speed of communication and conciseness.

It is worth mentioning that a new investigation into this terminology in the near future may reveal different results as this terminology changes significantly given the rapid advances in computer technology leading to the creation of new words on a daily basis. 


\section{REFERENCES:}

Athu, C., Influența limbii engleze asupra limbii române actuale. (În limbajul economic și de afaceri), Editura Universitară, București, 2011.

Ciobanu, G., Romanian Words of English Origin, second revised edition, Mirton, Timișoara, 2004.

Crystal, David, English as a Global Language, Cambridge University Press, Cambridge, 1997.

Crystal, David, Language and the Internet, Cambridge, Cambridge University Press, Cambridge, 2001.

Dimitrescu, Flotica, Dicționar de cuvinte recente, Logos, București, 1997.

Filipović, Rudolf, ed., The English Element in the Main European Languages, Zagreb University Press, Zagreb, 1982.

Görlach, M., (ed.), A Dictionary of European Anglicisms, A usage dictionary of Anglicisms in sixteen European languages, Oxford University Press, Oxford, 2001.

Görlach, M., (ed.), English in Europe, Oxford, Oxford University Press, Oxford, 2002.

Greffeinstern, S., The Influence of Computers, the Internet and Computer-Mediated Communication on Everyday English, Logos Verlag Berlin, Berlin, 2010.

Oprit-Maftei, C., English Borrowings in Romanian: Economic Terminologies, Europlus, Galați, 2018.

***, Oxford Collocations Dictionary, Oxford University Press, Oxford, 2002.

Popescu, F., Foreignisms in D. Bolintineanu's Novels, Lexic comun/Lexic specializat, Casa Cărții de Știință, Cluj-Napoca, 2015.

Pușcariu, Sextil, Limba română, I, Privire generală, Fundația pentru literatură și artă "Regele Carol al II-lea", București, 1940.

Radu, V., Limba engleză şi globalizarea, Amfora, Timișoara, 2009.

Van Sterkenburg, Piet, (ed.), Unity and Diversity of Language, Amsterdam, Philadelphia, John Benjamins, 2009.

\section{CORPUS}

Știrile PROTV https://stirileprotv.ro/ilikeit/smart-things/ilikeit-cateva-explicatiidespre-gdpr-noul-pachet-legislativ-care-se-aplica-din-25-mai.html [retrieved 10 December 2018]

Ziarul financiar, https:/ / www.zf.ro, 26 January; 3 April; 2, 25, 28 May; 13 July; 7

September; 16, 31 October; 9, 15 November; 12, 14 December 2018

[retrieved 10 - 17 December 2018]

Capital, capital.ro, 14 December 2018 [retrieved 17 December 2018]. 


\begin{abstract}
The explosive development of computers and of the internet has slowly influenced almost every aspect of our lives. Nowadays we rely heavily on the use of technologies that enable instant transmission of ideas and information. Moreover, globalization has facilitated communication, thus enabling participation of world nations in global economy. The present paper devotes special attention to the English borrowings in computer science and computer-mediated communication since their number is increasingly higher. It also aims at providing a complex classification of computer science-related English borrowings with examples selected from the print or broadcast media, demonstrating that the Romanian computer lexicon is continuously changing, incorporating the most recent words that emerge to designate major developments in science and technology. The number of English borrowings is therefore increasingly higher as these words denote certain realities that do not have equivalents in Romanian or would require long explanatory paraphrases.
\end{abstract}

Key words: globalization, computer science terminology, English borrowings, literal translation. 